\title{
CONTENT OF NUTRIENTS COMPONENT AND FATTY ACIDS IN CHIA SEEDS (SALVIA HISPANICA L.) CULTIVATED IN ECUADOR
}

\author{
CARDENAS M, CARPIO C, MORALES D, ÁLVAREZ M, SILVA M, CARRILLO W*
}

Laboratory of Functional Foods, Faculty of Foods Science and Engineering, Technical University of Ambato. Av. Los Chasquis y Rio Payamino. Campus Huachi, CP 1801334, Ambato-Ecuador. Email: wi.carrillo@uta.edu.ec

Received: 15 January 2017, Revised and Accepted: 05 May 2017

ABSTRACT

Objective: The aim of this work was to determine the fatty acids content in chia seeds oil (Salvia hispánica L.) sample cultivated in Ecuador.

Methods: Chia oil was obtained from chia seeds using the cold pressing method. Methyl esters fatty acids (FAME) analysis was carried out using the gas chromatography (GC) method with a mass selective detector (MSD) and using the database Library NIST14.L to identify the compounds present in the oil of chia seed.

Results: Methyl esters fatty acids were identified from chia (Salvia hispanica L.) seeds using the GC-mass spectrometer (GS-MS) analytical method. The total protein, lipid, and fiber content of chia seeds of plants cultivated in Ecuador was of 19.78, 16.06, and 27.88\%, respectively, of the total content on fresh weight. Fatty acids were analyzed as methyl esters on a capillary column DB-WAX 122-7062 with a good separation of palmitic acid, stearic acid, oleic acid, elaidic acid, linoleic acid, arachidic acid, and linolenic acid. The structure of FAME was determined using the GS-MS. Chia oil high content of linolenic acid (omega 3) with a value of $54.08 \%$ the total content of fatty acids in chia oil. 0 mega 6 content was of $18.69 \%$ and omega 9 content was of $10.24 \%$ the total content of fatty acids in chia oil.

Conclusions: Chia oil has a good content of fatty acids omega 3, 6, and 9. The higher value was of omega 3 with $54.08 \%$. Omega 3 is recommended to the prevention of risk cardiovascular.

Keywords: Chia, Salvia hispanica L., Fatty acids, Lipids.

(C) 2018 The Authors. Published by Innovare Academic Sciences Pvt Ltd. This is an open access article under the CC BY license (http://creativecommons. org/licenses/by/4. 0/) DOI: http://dx.doi.org/10.22159/ajpcr.2018.v11i2.17096

\section{INTRODUCTION}

Chia (Salvia hispanica L.) is a tropical and subtropical climates herbaceous plant belongs to the family Labiatae, originated from Mexico and northern and Guatemala. Food seeds have been important for human nutrition since $1500 \mathrm{BC}[1,2]$. Conventionally, chia seeds have been used as a food, in a wide range of traditional medicines, primary cosmetics, and a part of religious rituals in pre-Columbian civilizations [3]. Conventionally, chia seeds were used by Aztecs and Mayas people in the preparation of folk medicines, food, and canvases. Chia seeds are composition 22$24 \mathrm{~g} / 100 \mathrm{~g}$ of protein, $26-41 \mathrm{~g} / 100 \mathrm{~g}$ of carbohydrates, $18-30 \mathrm{~g} / 100 \mathrm{~g}$ of dietary fiber, $4-6 \mathrm{~g} / 100 \mathrm{~g}$ of ash, and $32-39 \mathrm{~g} / 100 \mathrm{~g}$ oil contents, also have important content of vitamins, minerals, and antioxidants [4]. The quality of edible vegetal oils is important for their acceptance as food or medicinal supplements because the fatty acids composition is a primary factor in its formulation. Chia seeds have a lower content of saturated fatty acids (palmitic and stearic acids), adequate concentration of linoleic acid omega 6 (18-20\%), and higher content of alpha-linolenic acid omega $3(55-60 \%)$ makes chia oil as a preferred and appealing choice for healthy food and cosmetic applications $[5,6]$.

\section{MATERIALS AND METHODS}

\section{Oil extraction}

Chia is cultivated in the central region of Ecuador. Chia oil sample was obtained from sambo seeds using the cold pressed method. Oil was then stored at $4.0 \pm 2{ }^{\circ} \mathrm{C}$. Oil extraction was conducted using a Soxhlet apparatus for approximately $5 \mathrm{~h}$ with hexane as solvent, with a solid-tosolvent ratio of $1 / 7 \mathrm{~m} / \mathrm{v}$. After the extraction process, the flask contents were filtered, and the liquid fraction containing the lipid extract and solvent was poured into a $250-\mathrm{mL}$ flask of a rotary film evaporator to remove the solvent. The obtained oil was collected, evaporated under nitrogen, weighed, and stored in sealed amber glass vials at $-20^{\circ} \mathrm{C}$ until analysis [7].

Fatty acids analysis by gas chromatography-mass selective detector (GC-MSD)

The fatty acid composition of oil extracted from chia seeds was analyzed by injecting fatty acid methyl esters (FAME) [8] into an Agilent Technologies 7980A system GC (Agilent, Santa Clara, CA) equipped with a MSD 5977A GC/MSD, an auto-sampler 7693, column (60 $\mathrm{m} \times 250 \mu \mathrm{m} \times 0.25 \mu \mathrm{m}$, Agilent 122-7062). The oven temperature was programmed as follows: From $80^{\circ} \mathrm{C}$; ramp 1: To $100^{\circ} \mathrm{C}$ at $20^{\circ} \mathrm{C} / \mathrm{min}$ during $1 \mathrm{~min}$; ramp 2: At $200^{\circ} \mathrm{C}$ at $25^{\circ} \mathrm{C} /$ min during $10 \mathrm{~min}$; and ramp 3: At $250^{\circ} \mathrm{C}$ at $2^{\circ} \mathrm{C} / \mathrm{min}$. The injector and detector temperatures were set at $250^{\circ} \mathrm{C}$. Helium was used as carrier gas at a linear flow velocity of $1.4 \mathrm{~mL} / \mathrm{min}$

\section{RESULTS}

\section{Proximate analysis}

The results of proximate analysis of chia seeds (S. hispanica L.) are shown in Table 1. The chia seeds from Ecuador content $19.78 \%$ of protein, the content of fat of chia seed were of $16.06 \%$. The content of fiber was of $27.88 \%$ and content of carbohydrates was high with a value of $31.46 \%$. In Fig. 1 shows chia seeds from Ecuador. These seeds are of small size with $2 \mathrm{~mm}$ approximately and with dark spots. All seeds present similar color and sizes.

\section{GC analysis}

The GC chromatogram of FAME from chia oil present five majoritarian peaks that were separated with a column Agilent DB-WAX 122-7062. 
These peaks were identified with the help of a spectrum of database NILTS14. L. The quantification of fatty acids was obtained using the peak area ratio. Fig. 2 shows seven majoritarian peaks with an excellent separation and definition, these peaks were identified such C16:0 with a retention time of $19.283 \mathrm{~min}, \mathrm{C} 18: 0$ with a retention time of $25.929 \mathrm{~min}$, C18:1 with a retention time of 26.750 min, C18:1 trans with a retention time of 27.101, C18:2 with a retention time of $28.557 \mathrm{~min}, \mathrm{C} 18: 3$ with a retention time of $31.036 \mathrm{~min}$, and finally was possible identified other peak $\mathrm{C} 20: 0$ with a retention time of $34.022 \mathrm{~min}$.

\section{Concentration of FAME}

The concentration of FAME from chia oil was measured using the peak area ratio. Table 2 summarizes C16: With $8.545 \pm 0.212 \%$ of fatty acid total content, C18:0 With $3.375 \pm 0.0071 \%$ of fatty acid total content, C18: 1 with $10.240 \pm 0.0141 \%$ of fatty acid total content, C18: 1 trans with $0.815 \pm 0.0071 \%$ of fatty acid total content, C18:2 with $18.69 \pm 0.0283 \%$

Table 1: Proximate analysis of chia seeds

\begin{tabular}{ll}
\hline Analysis & Content (\%) \\
\hline Ash & $4.82 \pm 0.025$ \\
Moisture & $5.71 \pm 0.032$ \\
Fat & $16.06 \pm 0.038$ \\
Protein & $19.78 \pm 0.015$ \\
Fiber & $27.88 \pm 0.021$ \\
Carbohydrates & $31.46 \pm 0.062$ \\
\hline
\end{tabular}

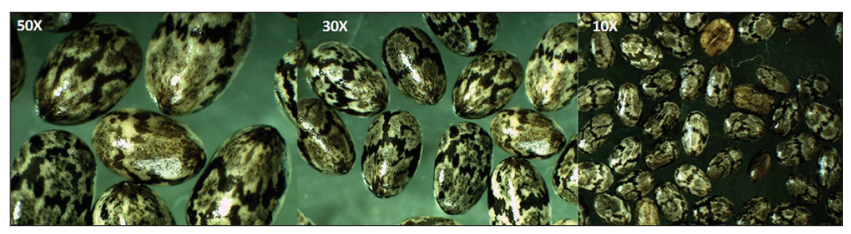

Fig. 1: Photographic of chia seeds from Ecuador at different augment of fatty acid total content, and C18:3 with $54.08 \pm 0.0141 \%$ of fatty acid total content of chia oil, and finally C20:0 with $5.065 \pm 0.0212 \%$ of fatty acid total content. Chia seeds present high content of polyunsaturated fatty acids (PUFA) C18:3 acids with $54.08 \pm 0.0141 \%$ of fatty acid total content.

The mass spectrum of FAMEs obtained from chia oil is shown in Fig. 2. The identity and structures of these fatty acids were confirmed by the GC-MS method. Palmitic acid (C16:0) was identified using the mass spectrum with ions of mass/charge $(\mathrm{m} / \mathrm{z})$ between 57 and $270 \mathrm{~m} / \mathrm{z}$. In the previous range, the ions 74 and $87 \mathrm{~m} / \mathrm{z}$ were the most abundant in the mass spectrum (Fig. 3a). Stearic acid (C18:0) (Fig. 3b), oleic acid (C18:1) (Fig. 3c), linoleic acid (C18:2), and linolenic acid (C18:3) (Fig. 3b-e).

\section{DISCUSSION}

In this study, content of protein of chia seeds from Ecuador presents a value of $19.78 \%$. Ullah et al., 2015 [9] reported protein content ranged 15-25\% form chia seeds, our value is between this limit [9]. The protein content of chia seed grown in different habitats ranged from $18.8 \%$ to $21.5 \%$, the variation in protein content was probably be due to agronomic, climatic, and soil conditions [10]. Content of fat of chia seed was of $16.06 \%$. Ixtaina et al., 2008 reported $30-33 \%$ of fat in chia seeds, us value is less than value. In Argentina, it reported different values of content of oil from chia with value of 32.2-36.8 compared with 35.6-38.6\% [11]. The difference of content oil could be connected to the difference in climatic conditions, agronomic practices, fertilization regimes, irrigation practices, etc.[12]. The higher values of tocopherols can have a positive impact on the storage stability of chia oil. Content of fiber was of $27.88 \%$. Protein, lipids, and fiber are biocompounds have good acceptation in the consumers. European accepted that chia can be such as functional food. Chia seeds are considerate safe without harmful effects for health for this reason can be in baked goods, nutritional supplements, cereal bars, cookies, bread, snacks, etc. Actually, chia seeds are used such component of several food in Mexico, Argentina, Chile, Ecuador, Canada, US, and Japan to different purposes. The US dietary guidelines recommend consuming chia seeds

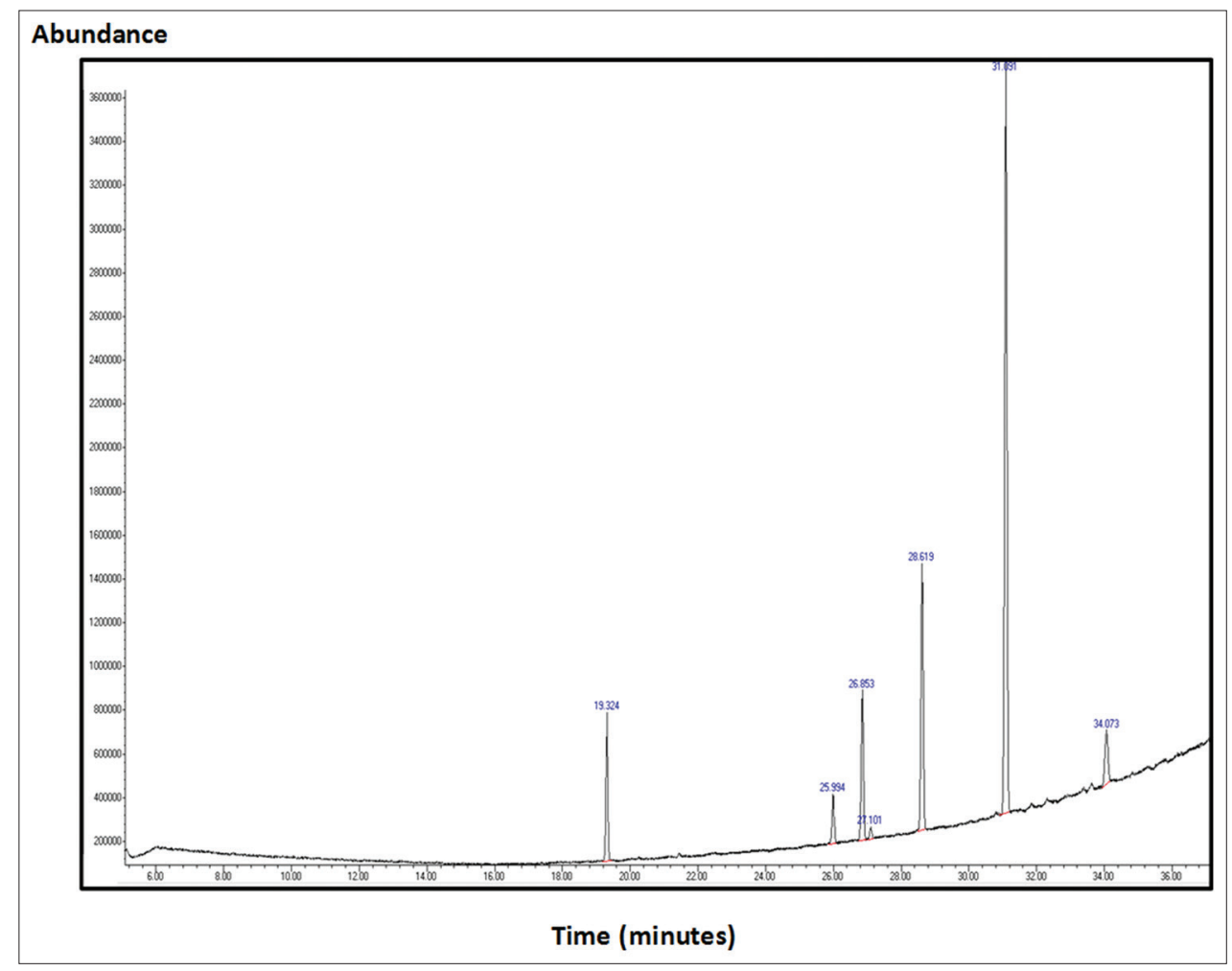

Fig. 2: Gas chromatography-mass spectrometer analysis of methyl esters fatty acids present in chia oil sample from Ecuador 
Table 2: Total lipid and fatty acids composition of chia oil sample from Ecuador by GC/MS analysis and their content

\begin{tabular}{|c|c|c|c|c|}
\hline Retention time (min) & FAMEs & Structural formula/chemical name & Numbers of Carbons & Percentage peak area \\
\hline 19.283 & Palmitic acid & Hexadecanoic acid & C16:0 & $8.545 \pm 0.0212$ \\
\hline 25.929 & Stearic acid & Octadecanoic acid & C18:0 & $3.375 \pm 0.0071$ \\
\hline 26.750 & Oleic acid & Cis-9-octadecenoic acid & C18:1 & $10.240 \pm 0.0141$ \\
\hline 27.101 & Elaidic acid & trans-9-octadecenoic acid & C18:1 trans & $0.815 \pm 0.0071$ \\
\hline 28.557 & Linoleic acid & $(9 \mathrm{Z}, 12 \mathrm{Z})-9,12-$-Octadecadieno & C18:2 & $18.69 \pm 0.0283$ \\
\hline 31.036 & Linolenic acid & (9Z,12Z,15Z)-octadeca-9,12,15-trienoic acid & C18:3 & $54.08 \pm 0.0141$ \\
\hline 34.022 & Arachidic acid & Eicosanoic acid & C20:0 & $5.065 \pm 0.0212$ \\
\hline
\end{tabular}

GC/MS: Gas chromatography/mass spectrometer, FAMEs: Methyl esters fatty acids

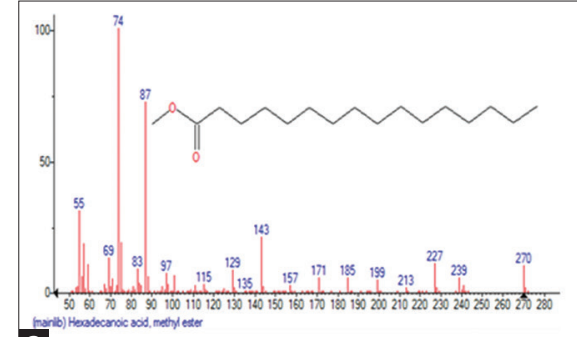

a

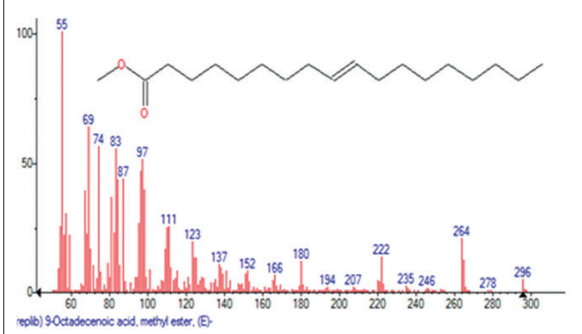

c

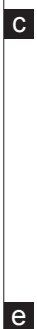

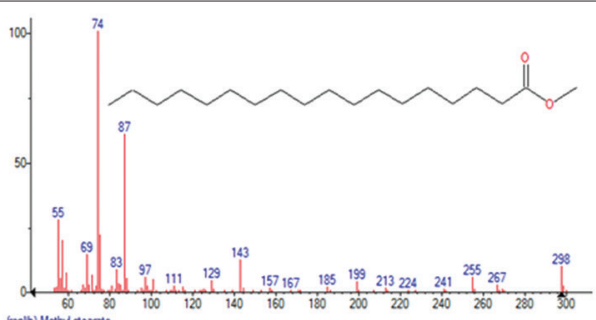

b

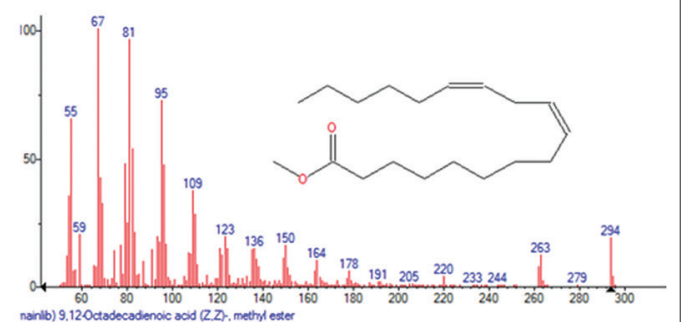

d

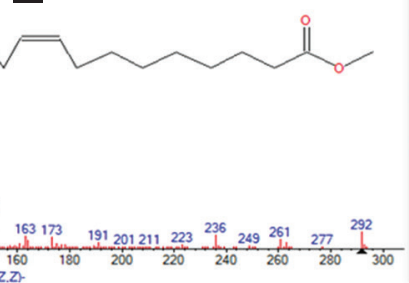

Fig. 3: : (a-e) Mass spectrum of methyl esters fatty acids from chia oil

for healthy as a primary source of good food, chia sprouts are used in salads, chia seed is used in beverages and cereal-based foods, and chia seeds can be consumed in raw form [13]. American Heart Association also directs the consumers to shift from saturated fats to unsaturated oils [14]. Foods with lower contents of saturated fatty acids are the order of day and in recent year's significant increase in the demand of such products have been observed. The great deal of shifting from saturated fats to unsaturated sources of oils is greatly attributed to the large 
number of incidences of cardiovascular diseases, hypertension, obesity, diabetes, and other health-related disorders [15]. The situation has led to the increased consumption of functional foods containing higher content of PUFA. Ali et al., 2012 reported content of PUFA of chia seed with value of $64 \%$ to $\bowtie 3$ and a value of $19 \%$ to $\bowtie 6$. Ixtaina et al., 2011 reported high content of PUFA from chia seeds with a value of $19.1 \%$ to $₫ 6$ and a value of $64.7 \%$ to $₫ 3$. Alvarez-Chávez et al., 2008 reported high content of PUFA from chia seeds with a value of $19.9 \%$ to $\bowtie 6$ and a value of $63.4 \%$ to $₫ 3$. Coates and Ayerza, 1998 reported high content of PUFA from chia seeds with a value of $7.63 \%$ to $₫ 6$ and a value of $63.20 \%$ to $๑ 3$ [16]. Ayerza, 1995 reported a content of $17.65 \%$ of $₫ 6$ and a value of $64.08 \%$ to $ه 3$. Us relation of $₫ 3 / \infty 6$ was of $18.64 / 54.08 \%$ chia seeds present high content of omega 3 [17]. Vegetable oils are utilized for many food and industrial activities. In nature, there is a great variety of vegetable oils sources, however in the world, consumption of vegetal oil is mostly by palm, soybean, rapeseed, and sunflower oils with 38.1, 35.7, 17.8, and 18.2 million tons consumed per year, respectively [18]. In recent year, there is interest in the development of new plant species as a source of dietary or specialty oils with good composition of monounsaturated and PUFA. Omega 3 is an important fatty acid of long-chain-PUFA ( $\omega 3$ LCPUFA) [19]. These fatty acids are increase being used in the prevention and treatment of several cardiovascular risk factors. $\omega 3$ and $\omega 6$ PUFA families are considered essential fatty acids, as the human body is itself unable to synthesize them. Cardiovascular disease is the leading cause of mortality in many economically developed countries, and its incidence is increasing at a rapid rate in emerging economies [20-22]. Diet and lifestyle issues are very associated with a myriad of cardiovascular disease risk factors including abnormal plasma lipids, hypertension, insulin resistance, diabetes, and obesity, suggesting that diet-based approaches may be of benefit.

\section{CONCLUSION}

Chia plant is a good source of vegetal oil with good composition of monounsaturated and PUFA. Chia oil has high content of linolenic acid $₫ 3$ with a value of $54.08 \%$. Omega 3 is recommending to prevent risks cardiovascular. Chia oil is also content good proportion of omega 6 and 9 with the value of 18.69 and $10.24 \%$, respectively. Chia oil is a good biocompound that can be used to include in the food industry to different uses.

\section{ACKNOWLEDGMENTS}

This study was supported by Universidad Técnica de Ambato, Ecuador (Project CPU-1373-2014-UTA) and Project Canje de DeudaEspañaEcuador. This work has been reviewed in the English edition by Emilio Labrador.

\section{AUTHOR CONTRIBUTIONS}

Carrillo W, Cardenas M, Carpio C, and Morales D conceived and designed the experiments. Silva M and Alvarez M performed the gas chromatography analyses. Carrillo W wrote the paper.

\section{CONFLICT OF INTEREST}

The authors declare no conflict of interest.

\section{REFERENCES}

1. Ayerza R Jr, Coates W. Effect of dietary alpha-linolenic fatty acid derived from chia when fed as ground seed, whole seed and oil on lipid content and fatty acid composition of rat plasma. Ann Nutr Metab 2007;51:27-34.
2. Ayerza R, Coates W. Composition of chia (Salvia hispanica) grown in six tropical and subtropical ecosystems of South America. Trop Sci 2004;44:131-5.

3. Coates W, Ayerza R. Chia (Salvia hispanica L.) seed as an n-3 fatty acid source for finishing pigs: Effects on fatty acid composition and fat stability of the meat and internal fat, growth performance, and meat sensory characteristics. J Anim Sci 2009;87:3798-804.

4. Coates W. Protein content, oil content and fatty acid profiles as potential criteria to determine the origin of commercially grown chia (Salvia hispanica L.). Ind Crop Prod 2011;34:1366-71.

5. Peiretti PG, Ga F. Fatty acid and nutritive quality of chia (Salvia hispanica L.) seeds and plant during growth. Anim Feed Sci Technol 2009; 148:267-75.

6. Reyes-Caudillo E, Tecante A, Valdivia-López MA. Dietary fibre content and antioxidant activity of phenolic compounds present in Mexican chia (Salvia hispanica L.) seeds. Food Chem 2008;107:656-63.

7. Gutiérrez LF, Rosada LM, Jiménez A. Chemical composition of Sacha Inchi (Plukenetia volubilis L.) seeds and characteristics of their lipid fraction. Grasas Aceites 2011;62:76-83.

8. House SD, Larson PA, Johnson RR, DeVries JW, Martin DL. Gas chromatographic determination of total fat extracted from food samples using hydrolysis in the presence of antioxidant. J Assoc Off Anal Chem 1994;77:960-5.

9. Ullah R, Nadeem M, Khalique A, Imran M, Mehmood S, Javid A, et al. Nutritional and therapeutic perspectives of chia (Salvia hispanica L.): A review. J Food Sci Technol 2016;53:1750-8.

10. Ting IP, Brown JH, Naqvi HH, Estilai A, Kummamoto J, Matsumura M. Chia: A potential oil crop for arid zones. In: Naqvi HH, Estilai A, Ting IP, editors. New Industrial Crops and Products. Tucson, AZ: University of Arizona; 1990. p. 197-200.

11. Ixtaina VY, Nolasco SM, Tomas MC. Physical properties of chia (Salvia hispanica L.) seeds. Ind Crop Prod 2008;28:286-93.

12. Ayerza R. Seed yield components, oil content, and fatty acid composition of two cultivars of moringa (Moringa oleifera Lam.) growing in the Arid Chaco of Argentina. Ind Crop Prod 2011;33:389-94.

13. Ali NM, Yeap SK, Ho WY, Beh BK, Tan SW, Tan SG. The promising future of chia Salvia hispanica L. J Biom Biotechnol 2012. DOI: $10.1155 / 2012 / 171956$

14. USDA. Dietary Guidelines for Americans. Home and Garden Bull. No. 232, 11. $5^{\text {th }}$ ed. Washington, DC: US Depts of Agriculture and Health and Human Services; 2000.

15. Hansel B, Nicolle C, Lalanne F, Tondu F, Lassel T, Donazzolo Y, et al. Effect of low-fat, fermented milk enriched with plant sterols on serum lipid profile and oxidative stress in moderate hypercholesterolemia. Am J Clin Nutr 2007;86:790-6.

16. Ixtaina VY, Martinez ML, Spotorno V, Mateo CM, Maestri DM, Diehl BW, et al. Characterization of chia seed oils obtained by pressing and solvent extraction. J Food Compos Anal 2011;24:166-74.

17. Coates W, Ayerza R. Commercial production of chia in Northwestern Argentina. J Am Oil Chem Soc 1998;75:1417-20.

18. Ayerza R. Oil content and fatty acid composition of chia (Salvia hispanica L.) from five northwestern locations in Argentina. J Am Oil Chem Soc 1995;72:1079-81.

19. American Soybean Association Soy Stats. Reference Guide to Important Soybean Facts and Figures. From the SoyStats Home Page; 2007. Available from: http://www.soystats.com/default.htm. [Last retrieved on 2008 May].

20. Ayerza R, Coates W. An $\omega-3$ fatty acid enriched chia diet: Influence on egg fatty acid composition, cholesterol and oil content. Can J Anim Sci 1999;79:53-8

21. Suhadi R, Thobari J, Irawan B, Dwiprahasto I. The blood pressure and therapy expenditure change due to hypertension comorbidity: An analytical prospective study in secondary care hospitals in Jogjakarta Indonesia. Int J Pharm Pharm Sci 2016;8:78-83.

22. Tolba M, Khashab K, Said A. The effect of dipeptidyl peptidase-4 inhibitors on cardiovascular disease risk in Type 2 diabetes mellitus. Int J Pharm Pharm Sci 2016;9:254-9. 